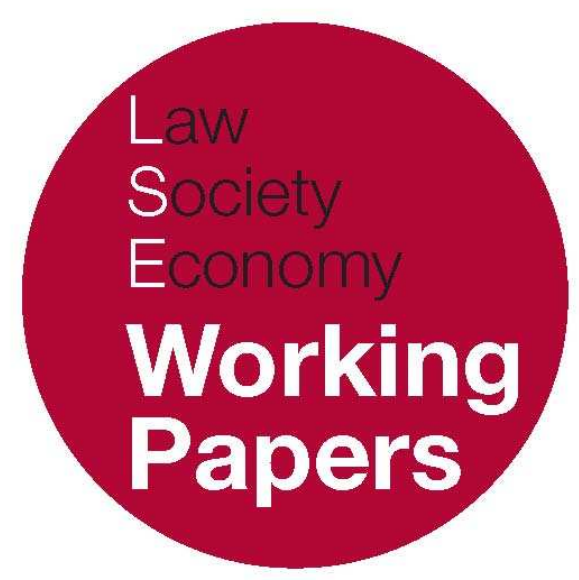

Seizing Truths: Art, Politics, Law

\author{
Igor Stramignoni
}

LSE Law, Society and Economy Working Papers 14/2010 London School of Economics and Political Science

Law Department

This paper can be downloaded without charge from LSE Law, Society and Economy Working Papers at: www.lse.ac.uk/collections/law/wps/wps.htm and the Social Sciences Research Network electronic library at: http://ssrn.com/abstract=1622392.

(C) Igor Stramignoni. Users may download and/or print one copy to facilitate their private study or for non-commercial research. Users may not engage in further distribution of this material or use it for any profit-making activities or any other form of commercial gain. 


\title{
Seizing Truths: Art, Politics, Law
}

\author{
Igor Stramignoni ${ }^{*}$
}

\begin{abstract}
The work of French philosopher Alain Badiou has been described as the most powerful alternative yet conceived in France to the various forms of postmodernism that arose after the collapse of the Marxist project. Art interests Badiou in its own right but also as both that which, in the twentieth century, eclipsed philosophy and as that which today philosophy, increasingly de-sutured from art, must imitate in order to make clear that there are truths after all. Badiou conceives of law, on the other hand, as part and parcel of a specific political machine that must continuously perform certain problematic exclusions if it is to keep the fiction of parliamentary democracy together. So how is the relationship between art and law, between the poet and the city, in Badiou's oeuvre?
\end{abstract}

\footnotetext{
* Law Department, London School of Economics and Political Science. A shorter version of this essay was presented at the symposium 'Law and Art: Ethics, Aesthetics, and Justice' held at the Tate Modern in London on 23 March 2010 .
} 
Woher, in aller Welt, bei dieser Constellation

der Trieb zur Wahrbeit!

[F. Nietzsche $]^{1}$

Quel sera le destin de la pensée, Dont on sait bien qu'elle est invention affirmative, Ou qu'elle n'est pas? $[\text { A. Badiou }]^{2}$

\section{INTRODUCTION}

The invitation to consider the relationship between art and law is, after all, a philosophical invitation, a question for thought. Or is it? The scene, as we know, was set long ago, when in Plato's Republic Socrates first issues Homer, the great poet of antiquity, with the rather biting indictment of having been neither a Lycurgus nor a Solon, and then proceeds to banish poetry from the city except when it comes to 'hymns to the gods and eulogies to good people' or else, when it is readmitted because 'it has successfully defended itself, whether in lyric or any other meter'. ${ }^{3}$ It is thus commencing with Plato that good government comes to be seen as fundamentally separate from and better a world than that of art so that 'law', too, comes to be understood as 'not poetry'. We are still, here, in the business of naming, and it will take Aristotle to turn naming into categories and then the praetor's edictum to turn categories into personae, res, and actiones - as Cicero, for one, was quick to appreciate. And yet, for a long time, recourse to poets and to poetry and to their auctoritas or knowledge will be treated with suspicion by philosophy, politics, and law, for even Virgil, it came to be feared, may prove a misleading witness (falsus testis) or else because, rather more annoyingly, thus do many who know nothing yet manage to earn twice as much money as those who have the correct knowledge (sic faciunt multi qui nibil sciunt, sed lucrantur bis tamen quam illi qui bene sciunt). For a long time, then, the city and its laws will evoke poets and poetry so that they could banish them thus affirming or reaffirming their own command or their own legitimacy, if not always their own prestige.

\footnotetext{
1 'From whence, in the Universe, does the impulse for truth come to this Constellation?' [Translations in this essay are mine, unless otherwise noted].

2 'What will the destiny of thought be, which we know well that it is affirmative invention, or nothing at all?'

${ }_{3}^{3}$ Plato, Complete Works (Indianapolis/Cambridge: Hackett, Eng tr, 1997).
} 
This long-standing arrangement went through several important permutations in Western Europe but its deeper significance was to be questioned upon what Jean-Francois Lyotard famously called the 'linguistic turn' of Western thought. Earlier on, Newton had explained, Descartes doubted, and Kant transcended but it was probably Nietzsche the last metaphysician (as Heidegger was to argue) or, indeed, the first of a new breed of thinkers to submit fully to the ultimate effect of modernity by actually venturing or wandering into a dimmed or darkening world whereby, it appeared, the breakdown of any primordial notion of authority or tradition had paved the way for the lessening or loosening of the authority or grip of any old and modern philosophical truth, scientific knowledge, political arrangement, artistic creation, and even amorous declaration. In that gloomier or no longer so luminous a world, the idea of art of course but also that of ethics, jurisprudence, or law sink back into their embodied or finite histories and from there into the turmoil of their individual or collective memories and to the clamour, or perhaps the murmur, of their voices. They become, in Nietzsche's famous expression, figurative all the way down (even Hobbes might have agreed with that). Thus if indeed 'the effort of social thought and philosophy since the Enlightenment can be described as an epic effort to ground knowledge and truth in a new age of radical rootlessness and doubt', ${ }^{4}$ the key question gradually if unevenly becomes not just what specific languages poets as opposed to legislators might speak, but also, ironically, what languages might speak something like 'law' or 'art', 'legislators' or 'poets', and even 'reason' or 'unreason', for example. Politically that meant, for some, the need of multiplying their efforts in order to rediscover the human or even just the common in ethics, aesthetics, or justice while, for others, the question clearly required attending to the margins of the Western subject or even removing to the 'open'. At a time when the human exploitation of life on earth has reached an unparalleled intensity in human history, others have concluded instead that it is technology as techne that speaks, or that so often speaks, the language of many languages. And so then it is technology that might provide the missing link or, depending on one's views, inaugurate the hidden tensions that are supposed to exist today between, for example, the world of art and the world of law.

This is of course a highly selective and probably insufficient picture of what really happened during much of the twentieth century. However the point here is neither to map out such a complex event as the linguistic turn nor to debate whether such turn was, after all, more persuasive in its various 'continental' instantiations or in its equally numerous 'analytical' applications, nor, finally, to consider whether or not the former could be seriously regarded to be eminently 'American', as Cusset perhaps understandably suggests. Instead the point here is to register how by the beginning of the twenty-first century the model of language,

${ }_{4}$ C. Douzinas, R. Warrington, and S. McVeigh, Postmodern Jurisprudence (London and New York: Routledge, 1991) 9. 
Frédéric Worms has recently argued, appears to be dwindling. ${ }^{5}$ For Worms, the present moment (moment présent) appears to be marked by a return (réprise) of philosophy and of history and, on the other hand, of philosophy and of the life sciences. The question then - and it must remain an open question, at least for the time being - is less whether we are in for a return to such disciplines - if there is one thing that the linguistic turn will have conclusively demonstrated that is just how porous the boundaries of disciplines can be - than it is, one might argue, to examine how each of those fields of inquiry might be shaping up in the aftermath of an event that has 'hit' them in a way that can hardly be ignored or, for that matter, revoked into doubt. Language, one feels, has come (back) to stay, at least for a little longer than some of its detractors might hope. The more interesting problem then may be whether, by now, anything else is on offer which would help us think the contemporary situation and, here, the relationship between art and law, the poet and the city, afresh.

In such a fluid or confused situation - where the 'confusion' seems to belong to the present rather than to any particular field of inquiry such as, for example, philosophy or history ${ }^{6}$ - the work of French philosopher Alain Badiou occupies a unique position for its continued defence and imaginative deployment of a certain Platonism. In a short but powerful text published in 1992 and entitled The (Re)turn of Philosophy Itself, Badiou sums up his general thesis regarding philosophy in four key points. The first one is that philosophy itself must recommence. The second point is that philosophy must break with historicism: 'Philosophy must determine itself in such a way as to judge its history itself, and not to have its history judge it." The third point is that a definition of philosophy does in fact exist and, importantly, can be distinguished from both early and latter-day or postmodern philosophical sophistry. Early sophists 'maintain that thought is [...] either effects of discourse, language games, or the silent indication, the pure "showing" of something subtracted from the clutches of language'. ${ }^{8}$ Latter-day sophists, by contrast, argue for 'a general equivalence of discourses, a rule of virtuosity and obliquity' attempting 'to compromise the very idea of truth in the fall of historic narratives' and critiquing Hegel and philosophy itself 'to the benefit of art, or Right, or an immemorial or unutterable Law'. ${ }^{9}$ In general, sophists are to be taken with a pinch of salt in so far as they seek 'to set the strength of the rule, and, more broadly, modalities of the linguistic authority of the Law against the revelation or production of the true'. ${ }^{10}$ Finally, the fourth and perhaps most important point is, for Badiou, that there are truths after all, and that to stand by that evidence is neither to embrace the sort of idealism criticised by a certain Marxism, nor to subscribe to

\footnotetext{
${ }^{5}$ F. Worms, Philosophie en France au XX Siècle (Paris: Gallimard, 2009).

6 Worms, n 5 above, 555.

7 A. Badiou '(Re)turn of Philosophy Itself' in A. Badiou (ed), Manifesto for Philosopby (1992, Albany: SUNY, Eng tr, 1999) 115-116.

8 ibid, 116.

9 ibid, 117.

10 ibid, 118.
} 
Heidegger's historical meditation, nor, finally, to turn yet again to Plato's mathematical objects and to what Anglo-Saxon analytical philosophy might dismiss as a 'metaphysics of the supra-sensible'. ${ }^{11}$

Badiou's four theses are designed to declare the end of the end of philosophy and so to reopen 'the Plato question [...] to examine whether it is not by an other Platonic gesture that our future thinking must be supported'.12 Such a gesture would recognise how the operational or logical Truth of Platonic philosophy is that in the beginning there are truths that philosophy will have subsequently declared to be compossible. Or, philosophy is, in a way that will have to be further examined, a possible and necessary yet purely subtractive operation designed to produce the effect of Truth as against the effect of sense and an operation, moreover, that is 'driven by the intensity of love without an object' and by means of 'a persuasive strategy without any stakes in power'.13

Thus for Badiou the question of the relationship between art and law becomes at first a question of thinking four distinctive truth procedures in their ontological, logical, and subjective dimensions:

We shall thus posit that there are four conditions of philosophy, and that the lack of a single one gives rise to its dissipation, just as the emergence of all four conditioned its apparition. These conditions are: the matheme, the poeme, political invention and love. We shall call the set of these conditions generic procedures. ${ }^{14}$

Such a striking task presents at least two preliminary challenges for those who are interested in the question of the relationship between art and law as this might present itself from Badiou's point of view. On the one hand, Badiou's critique seems to be built on the assumption of a continuity between legal and political arrangements that some legal and political theorists might find difficult to recognise, let alone accept. ${ }^{15}$ On the other hand, such a critique could be seen to reinstate philosophy, and for no obvious reason, into its long-standing aspiration to arbitrate over that 'ancient quarrel' between the city and the poet that Stanley Rosen has recently re-examined. And yet, Badiou's philosophy - which, he never tires of repeating, does not produce truths of its own but merely 'configurates the becoming-disparate of the system of its conditions by construction of a space of thoughts of the time'16 - may be attractive precisely because we live in a time when global capitalism seems to have brought about a hazy state of fragmentation that, oddly enough, leaves us stranded with a somewhat limited alternative between the rather disconcerting spectacle of an endless number of paradoxical or

\footnotetext{
11 ibid, 121.

12 ibid, 122. See A. Toscano, 'To Have Done with the End of Philosophy' (2000) 9 PLI 220.

${ }^{13}$ Badiou, $n 7$ above, 127.

14 A. Badiou, 'Manifesto for Philosophy' in A. Badiou, $\mathrm{n} 7$ above, 35.

${ }^{15}$ M Shapiro, 'Law and Politics: The Problem of Boundaries' in K. Whittington, R.D. Keleman, and G. Caldeira (eds), The Oxford Handbook of Law and Politics (Oxford: OUP, 2008).

${ }^{16}$ Badiou, $n 14$ above, 39.
} 
self-referential legal, political, artistic, and other domains (or even eigenvalues), and on the other hand an equally endless albeit contrasting horizon of overlapping discourses or regimes such as that of the political, the juridical, the cultural, and so on and so forth. In such an obviously unsustainable situation, are those domains or those overlapping discourses or regimes not in need to be thought afresh, and otherwise? Can we think that which pertains to art, politics, and law separately and yet together rather than treating them, by contrast, either as essentially different or as essentially in-different worlds, that is to say, in a way that either would hopelessly accelerate their reciprocal isolation or that, alternatively, would dissipate them into a baffling communicative continuum where no difference is, ultimately, really possible or even just desirable? And indeed, is there an alternative to the danger of complacent introspection that is somehow unavoidable in difference and even more so in self-reference and, on the other hand, to the equally obscure danger of giving up thinking altogether? And what might that tell us of the specific question that concerns us here, that of the relationship between art and law in the work of Alain Badiou?

Finally, it is worth adding that Badiou's recent publication of numerous new essays, as well as the publication of Logiques des mondes (Part II of his major earlier work, L'être et l'événement), are being hotly debated, unsurprisingly in my view, well beyond academia. And indeed, to quote Peter Hallward, Badiou's work may well constitute the 'most powerful alternative yet conceived in France to the various forms of postmodernism that arose after the collapse of the Marxist project'. ${ }^{17}$ For Alberto Toscano, 'Badiou presents us with what is perhaps the most effective critique of the very conditions for what has become the nostalgic, crepuscular, and ultimately reactionary tonality of much of European philosophy. ${ }^{18}$ For Christopher Norris, 'Badiou's thinking is remarkable chiefly for taking so strong and principled a stand against just about every major direction of the present-day philosophic tide.' ${ }^{\prime 19}$ And finally even Peter Goodrich admits, albeit one suspects obtorto collo, that 'Badiou has taken over the coveted spot of regnant French philosopher in the Anglophone world'. ${ }^{20}$

\section{ART, PHILOSOPHY, AND TRUTH}

Art occupies a somewhat enigmatic place in Badiou's oeuvre. On the one hand, Badiou argues, art qua language has, since Nietzsche, Wittgenstein, and Heidegger, adopted or even appropriated certain functions that thus far had been on the whole the domain of philosophy qua (metaphysical) thought. And yet, for Badiou,

\footnotetext{
${ }_{17}$ P. Hallward, 'Generic Sovereignty: The Philosophy of Alain Badiou' (1998) Angelaki 87.

18 Toscano, n 12 above, 223.

${ }^{19}$ C. Norris, 'Some Versions of Platonism: Mathematics and Ontology According to Alain Badiou' (2008) Philosophical Frontiers 1, 1.

20 P. Goodrich, 'Preface (On Alain Badiou’s Handwriting)' (2008) 29 Cardozo L. Rev. 1867, 1867.
} 
the age of the poets is now completed and so philosophy must be untied or desutured from art. On the other hand, however, art and in particular poetry remains central to Badiou's philosophy, both as a key form of truth-event (together, that is, with science, politics, and love) and more specifically insofar as the poem, he explains, 'is language itself, in its solitary exposition as an exception to the noise that has usurped the place of comprehension'.21 Thus, one might say, art is not philosophy for Badiou, and yet the value of that negation, the value of that 'not', lies not in the banishment or even in what Jean-Luc Nancy might call l'être abandonné or Giorgio Agamben la messa al bando of art by philosophy, but rather in something like a recognition or foregrounding of the 'thought of the poem' itself, along with that of the thought of ontology or science (the matheme), of the thought of politics (the political invention), and of the thought of love.22 This is crucial for all sorts of reasons but here let us just stress how the shift almost imperceptibly operated by Badiou is from the subjection to an exception the rather dubious template that has become fashionable upon the 'rediscovery' in recent years of Carl Schmitt's contributions to constitutional theory - to differentiation by reinvention, repositioning, or reopening, and how this is an important shift if one is fully to grasp Badiou's highly distinctive take on art and philosophy. To be sure, philosophy for Badiou has always been tempted by poetry, and so poetry has always been 'the precise equivalent of a symptom' for philosophy. ${ }^{23}$ But poetry is the symptom of philosophy not, as tradition would have it, because poetry imitates while philosophy does in fact speak the truth but rather because poetry is a 'properly incalculable thought', wholly other than thought proper (mathematical thought or ontology). ${ }^{24}$ Art then is not philosophy, and philosophy is not art - but neither are matheme, political invention, or love. instead, they all sit together unconcerned, one might say, by one another, and that is what is most attractive for philosophy which in turn must make their different thoughts manifest in their compossibility. ${ }^{25}$ Take the Preface to the Italian edition of his Manifeste pour la philosophie:

Philosophy is the place of thought where the 'there are' of truths and their compossibility are declared. To that end, philosophy sets up an operative category, Truth, which opens up within thought an active void. Such a void is identified on the basis of the reverse of a sequence $[\ldots]$ and of the beyond of a limit. Philosophy, as discourse, operates thus a superimposition of two fictions, one cognitive and one artistic. ${ }^{26}$

\footnotetext{
21 A. Badiou, 'Language, Thought, Poetry' in R. Brassier and A. Toscano (eds), Theoretical Writings: Alain Badiou (London and New York: Continuum, 2006) 241.

22 A. Badiou, Handbook of Inesthetics (1998, Stanford, California: Stanford University Press, 2005).

23 A. Badiou, 'Notes' in R. Brassier and A. Toscano (eds), n 21 above, 245.

24 ibid, 246.

25 I. Stramignoni, 'Badiou's Nocturnal Jurisprudence’ (2008) 29 Cardozo L. Rev. 2361.

26 'La filosofia è il luogo del pensiero in cui si enuncia il "c'è" delle verità e la loro compossibilità. A tale fine, essa mette a punto una categoria operativa, la Verità, che apre nel pensiero un vuoto attivo. Tale vuoto è individuato in base all'inverso di una successione [...] e all'al di là di un limite [...] La filosofia,
} 
Thus philosophy for Badiou amounts to a 'subtractive' or 'nocturnal' discourse operating as a form of poetic as well as of cognitive fiction - that is to say, as something rigorous yet inventive. And ' $[\mathrm{i}] \mathrm{n}$ the void opened up by the gap or interval between the two fictions, philosophy seizes the truths. This seizing is its act'. ${ }^{27}$ As fiction of knowledge, Badiou explains, philosophical discourse qua discourse of truth imitates the matheme. As fiction of art, on the other hand, philosophical discourse imitates poetry. ${ }^{28}$ Finally philosophy imitates an objectless love through the intensity of its seizing. And as that which is directed towards all, philosophy imitates a political strategy without the power. ${ }^{29}$ Philosophy, in short, will be rigorously and poetically and passionately to state to all that there are truths after all.

In his Petit manuel d'inesthetique Badiou looks closer to the relationship of art and philosophy and puts forward the thesis according to which art should be understood as a truth procedure sui generis, both immanent and singular. This, he argues, would be an entirely novel philosophical proposition in a century that, for all its endings, breaks, and catastrophes, did not really depart from the three existing schemata of that relationship. Even Deleuze, Badiou adds, fails to appreciate the true extent to which art is both immanent and singular and so, consequently, the extent to which art thinks. And the reason for this is (deceptively) simple. 'This is because,' Badiou explains, 'if one fails to summon the category of truth in this affair, one cannot hope to succeed in establishing the plane of immanence from which the differentiation between art, science, and philosophy can proceed. ${ }^{30}$ The category of truth thus is needed if one is successfully to tell art, science, or philosophy from one another.

The first traditional schema of the relationship between philosophy and art is, for Badiou, the didactic schema whose twentieth century expression is exemplified, he argues, by Brecht's Marxist and 'scientific' theatre which, in its insistence on searching for the immanent rules of art produced 'an artistic invention of the first calibre within the reflexive element of a subordination of art'. ${ }^{31}$ According to the didactic schema 'art is incapable of truth, or [...] all truth is external to art. ${ }^{32}$ That is to say, art and philosophy are clearly separate endeavours. Indeed, art would be like Lacan's Hysteric in his or her relationship to the Master. It would seek to present itself in its nakedness to the philosopher, asking the philosopher to tell them who they are. Although charmed by it, the philosopher however would ultimately reject art's seduction on account that art in this way would constitute

come discorso, opera così la sovrapposizione di due finzioni, una di sapere e una d'arte.' A. Badiou, 'Prefazione all'Edizione Italiana' in Manifesto per la Filosofia (Napoli: Cronopio, 1991) 20.

27 'Nel vuoto aperto dallo scarto o intervallo tra le due finzioni, la filosofia coglie le verità. Questo coglimento è il suo atto.' ibid, 20.

28 'Finzione del sapere, la filosofia imita il matema. Finzione d'arte, imita la poesia.' ibid, 20.

29 'Intensità di un atto, essa è come un amore senza oggetto. Rivolta a tutti affinchè tutti colgano

l'esistenza delle verità, essa è come una strategia politica senza fini di potere.' ibid, 20.

30 Badiou, n 22 above, 10.

31 ibid, 6 .

32 ibid, 2. 
not only an imitation of things but, more seriously, an imitation of the effect of truth. The charge here would be as straightforward as it would be damming. If truth can exist as charm, then we are fated to lose the force of dialectical labor, of the slow argumentation that prepares the way for the ascent to Principle. We must therefore denounce the supposedly immediate truth of art as a false truth, as the semblance that belongs to the effect of truth. ${ }^{33}$ Alternatively, art in the didactic scheme would be permitted by philosophy insofar as it would undertake to be educational and so remain under philosophy's control. In such case, "the "good" essence of art is conveyed in its public effect, and not in the artwork itself. '34

In the romantic schema art alone, Badiou continues, is capable of truth. In the twentieth century the romantic schema finds a home, above all, within Heideggerian hermeneutics according to which the poet is sovereign and the thinker is nothing but the announcement of a reversal, the promise of the advent of the gods at the height of our distress, and the retroactive elucidation of the historicality of being. While the poet, in the flesh of language, maintains the effaced guarding of the Open'. ${ }^{35}$

Thus interpretation and poem in the romantic schema coincide or, which is the same, art is held to amount to the body itself of truth, or to the absolute subject, or true incarnation. Therefore art, not philosophy, would have the task of educating us, namely by explaining how the power of infinity is held captive by form and so delivering us 'from the subjective barrenness of the concept'. ${ }^{36}$

If the didactic schema hystericises art and the romantic one glorifies it, then the third schema, the classical or Aristotelian schema, Badiou argues, dehystericises art. Such schema is found, for example, in psychoanalysis and specifically in Freud's analyses of painting or in Lacan's externations regarding poetry and the theatre. While concurring with the didactic schema that art is incapable of truth, the classical schema finds such predicament to be unproblematic in so far as art, according to it, does not in fact claim to be truth. Neither revelatory nor cognitive, art's function is, in the classical schema, therapeutic. Thus if it is liked, art is good for the classical schema and whether or not it is actually true is irrelevant insofar as the artwork is liked as true. Here, in the classical schema, art is 'entirely exhausted by its act or by its public operation'. ${ }^{37}$ Art becomes quite literally a service and an educational one at that.

At the turn of a century - which, Badiou concludes, was simultaneously conservative and eclectic - we are however left with the saturation of the three existing schemata and attendant disrelation of art and philosophy, but also with the closure represented by a sort of synthetic, ubiquitous, didactico-romantic schema. Which then would be the way out of this rather unsatisfactory situation paralysing thought? The way out would be to recognise the relationship of art and

\footnotetext{
33 ibid.

34 ibid, 3 .

35 ibid, 6 .

36 ibid, 3 .

37 ibid, 5 .
} 
philosophy as marked by both the immanent and the singular character of art, and specifically to recognise art as 'a truth procedure [...] a thought in which artworks are the Real (and not the effect). And this thought, or rather the truths that it activates, are irreducible to other truths - be they scientific, political, or amorous. This also means that art, as a singular regime of thought, is irreducible to philosophy'.38

In Badiou's own and unique schema the pedagogical function of art would be laid bare by its arrangement of extant knowledge and subsequent exposure of some truth within. Art here would educate us to nothing else than its own existence and in so doing, educate us to encounter thought or else to think through a form of thought or, which is the same, to think thought [penser une pensée] through an artistic procedure's own singular way.

Which, finally, would be the appropriate unity of an immanent and singular art such as that which Badiou points out to? The artwork, no doubt, is 'the only finite thing that exists' which is precisely why, Badiou argues, the artwork cannot be what might allow us to think 'art' in a truly inventive way. Thus art is not the artwork while, at the same time, certain works will one day have been found to be the work of art (art, in other words, always precedes the artwork). Furthermore, art for Badiou must never be thought independently of a prior event - quoting Mallarmé, for example, Badiou reminds us how 'made, existing, [the poem] takes place all alone' 39 - under pain of falling head-on into an 'idealistic conception of invention' that Badiou (who is a materialist after all) cannot but reject. ${ }^{40} \mathrm{~A}$ 'fact of art' (not an event) and, as such, 'the local instance or differential point of a truth' (not, therefore, a truth), an artwork is rather what Badiou now designates as the subject of an artistic procedure or, which is the same, 'the subject point of an artistic truth'. ${ }^{11}$

Such complex analysis has important consequences for the eventual appreciation of the relationship of art and law in the work of Alain Badiou. First, the sole being of an artistic truth is the being of works as these weave being together after the event and 'by the chance of their successive occurrences'. ${ }^{42}$ Thus works are enquiries about truths and, as such, they are retroactively validated as real works of art whenever it is ascertained that such enquiries are new. Secondly, artistic truths are, then, 'artistic configurations initiated by an event $[\ldots]$ and unfolded through chance in the form of the works that serve as its subjects points'. ${ }^{43}$ Importantly, a configuration is, for Badiou, an 'identifiable sequence' rather than an art form, a genre or objective period in the history of art, or a technical dispositif. Thus, for example, the evental rupture of Greek tragedy, for Badiou, bears the name 'Aeschylus' understood as the index of a central void in

\footnotetext{
38 ibid, 9.

39 Badiou, n 23 above, 240.

40 Badiou, n 22 above, 11.

41 ibid, 12.

42 ibid.

43 ibid.
} 
the previous situation of choral poetry and as the initial event of tragedy as the configuration or identifiable sequence that runs from Plato or Aristotle to Nietzsche and which, however, reaches its point of saturation with Euripides. Thirdly and lastly, it cannot be for philosophy to think an artistic configuration. Rather, 'a configuration thinks itself in the works that compose it.' 44 A work or inquiry, in other words, tests an artistic configuration as this will have been upon its infinite completion and, in so doing, lets art be 'the thinking of the thought that itself is'. ${ }^{45}$

The overall result of Badiou's inaugural gesture in relation to art is that art is now successfully subtracted or unsutured from philosophy. And philosophy, for its part, has now been reassigned its job which, in relation to art, must be from now on to reinvent, reposition, or reopen art, and so neither to banish it (for what, after all, is to 'think' art in the traditional way if not to exclude it from the city?) nor, at the other extreme, to subject itself to it, to subject itself to an exception that, ironically, has become the rule. But if, as Badiou is adamant to stress, one should have the courage to declare that art is art, and philosophy is philosophy, how then is the relationship of art and law vis-à-vis one another?

An answer to that question can be found only after one has considered first how, in Badiou's oeuvre, politics plays out 'against' the law.

\section{LAW AND POLITICS}

Badiou himself refers sparingly to the legal rules and legal institutions of modernity. For him, as for Marx, modern capitalism leads to the expropriation of the means of production by some, which then the State in parliamentary democracy upholds and, through its laws and legal institutions, enforces and defends. Thus the law is always predicative, particular, and partial. It is, Badiou argues, the cipher of a finitude (le chiffre d'une finitude). So, for example, a law banning the use of the bijab at school is, for Badiou, a law required by capital in so far as it seeks to appropriate the femininity of a minority of young Muslim teenagers by instructing them to become exposed or unveiled as if commodities on show in the market place. Likewise, a law sorting out and then expelling those who are short of all the required documents (sans papiers) from those who, by contrast, can exhibit those documents, and so can stay, cannot be said to be the law of a truly democratic country. And finally, a party system that turns necessity into a figure of choice should not be surprised to discover that voters in a referendum might decide against a law they do not actually want. Accordingly, any concern with laws and with legal institutions must be taken to be implicit in any broader concern Badiou has with the State, with parliamentary democracy and so, today, with the 'political' (le politique) or what Badiou famously calls 'capitalo-

44 ibid, 14 (italics in the original).

45 ibid. 
parliamentarianism' (capitalo-parlamentarisme). Under capitalo-parliamentarism there is nothing but 'management and law'. 46 '[T] he rest', he adds, 'is literature. ${ }^{37}$

Badiou of course has always been concerned by the political, which for him is to be firmly distinguished from politics proper (la politique). In a recent series of lectures held at the Ecole Normale Superieure in Paris on occasion of the 2007 elections of the new French President, Badiou reflects for example on what he perceives to be the ambiguous or porous nature of the electoral mechanism in contemporary parliamentary democracies, that is to say, a mechanism that lies at the heart of the political. In the face of such ambiguity or porousness, which paradoxically may turn voting into an instrument of oppression and of exclusion rather than one of emancipation and of participation, Badiou urges the abandonment of any illusion about voting and the embrace instead of eight key points, the most important of which would be that there is after all one world. That, Badiou explains, is what is really at stake in politics today.

Others of course have maintained, like Badiou, that politics are to be clearly distinguished from the political. Indeed, such a distinction appears to be running through the whole of what is often termed 'left-Heideggerian', or interpretive, or genealogical, or postmodern, or deconstructive, or 'post-foundational' political thought, and, obversely, through the political philosophy of the likes of Carl Schmitt. However, for Badiou real politics do not dwell at the threshold, or next to, or in the interstices of, or elsewhere than, or at the margins of, the political, nor do they become utterly impotent or, alternatively, nuda vita vis-à-vis the political in the state of emergency. All to the contrary, real politics for Badiou eschew the political insofar as today what is presented by that name is a particular yet highly unstable mode (the State) of a particular yet highly unstable politics (parliamentarism) legitimated by a particular yet highly unstable definition of plurality (pluralism) and regulated by three particular yet highly unstable norms (economy, the nation, and democracy). The political coincides, for Badiou, with a no doubt potent but ultimately ineffective reification of politics that is carried out or at least encouraged by the particular political philosophy that has reigned sovereign and apparently unchallenged in contemporary parliamentary democracies and that holds 'politics - or, better still, the political - as an objective datum, or even invariant, of universal experience'. ${ }^{48}$

By contrast, real politics for Badiou are always plural and always brought about by multiple subjects who become such by virtue of their own singular relation to a truth-event. Above all, politics are a tearing away of the vacant surface of language which goes to form the 'state of the situation'. But what is the state of the situation? Structures for Badiou are certain inconsistent multiplicities that will have been counted as one. Thus inconsistency is at once the precondition and the residue of structural unification, as Badiou sees it. Yet structures are inexorably

\footnotetext{
46 A. Badiou, Second manifeste pour la philosophie (Paris: Fayard, 2009) 26.

47 ibid, 26.

48 A. Badiou, Metapolitics (1998, London and New York: Verso, Eng tr, 2005) 10.
} 
haunted by the void they obscure but cannot suppress. In set theory terms, such a void is neither a term nor the whole, neither something local nor something global, but rather a 'part' or sub-multiple that is included but does not belong. So if the void - 'which is the name of inconsistency in the situation' and which continually haunts presentation - is to be however superficially warded off, the structure of the situation needs not only to be presented, but also to be represented as such. ${ }^{49}$ Ontologically, then, the state of the situation is 'that by means of which the structure of a situation - of any structured presentation whatsoever is counted as one, which is to say the one of the one-effect itself, or what Hegel calls the One-One'. ${ }^{50}$ Or again, it is 'the riposte to the void obtained by the countas-one of its parts [which] proposes a clause of closure and security, through which the situation consists according to the one'. ${ }^{51}$ Finally, the state of the situation is always a separate or transcendental entity vis-à-vis the initial structure of the situation but also, and at the same time, the state of the situation is of that structure, immanent to it. That is to say, the state of the situation is both distinct from and linked to the initial structure so that this is 'furnished with a fictional being: the latter banishes, or so it appears, the peril of the void, and establishes the reign, since completeness is numbered, of the universal security of the one'. ${ }^{52}$

Politically, on the other hand, the State for Badiou is, with Marxism, a structure of domination defined by a principle of counting that is ultimately removed from or uninterested in - and yet, at the same time, historically tied to the individuals it counts. Thus the State is 'the law that guarantees that there is Oneness' and that 're-presents what has already been presented. ${ }^{53}$ And yet against Marxism and with Hobbes, the State for Badiou 'is not founded upon the social bond, which it would express, but rather upon un-binding, which it probibits. ${ }^{54}$ Thus the politics that follow on a political event will have been a dialectical interrupting of the State's ubiquitous representation of the situation that in turn will have triggered 'a show of power by the State' and so, then, will have put 'the State at a distance, in the distance of its measure'. ${ }^{55}$ Politics, in other words, is not the political but that which opens up a gap or a wound in the body of the dominant political fiction and, in so doing, Oliver Marchart notes, touches on the real. Or, politics is that which designates the order of truth and of the political event, and not, as is the case for Jean-Luc Nancy and Philippe Lacoue-Labarthe, the order of power and of police.

Thus instead of attempting to build one world out of the inevitable fragmentation and individuation sought out and fostered by modern capitalism and supported by democracy as this is normally understood, the question for Badiou would be how to declare the existence of one world, of one indivisible

\footnotetext{
49 A. Badiou, Being and Event (1988, London and New York: Continuum, Eng tr, 2005) 93.

50 ibid, 95.

51 ibid, 98 .

52 ibid.

53 ibid, 106 (italics are the author's).

54 ibid, 109 (italics are the author's).

55 ibid, 110.
} 
world that belongs to everybody, and so finally of a world that will have existed, all machinations to the contrary notwithstanding, even as these are supported, as they often are, by one form or another of repression or violence. In a world continuously broken down into nothing else than things and linguistic signs, the attempt must be therefore to declare that nevertheless, 'there is one world' where differences will be taken to be that which constitutes the world rather than that which divides it - such is what Badiou calls the 'transcendental' of the world whose immanent logical law it also is - and where particular laws exist that, however, are never really a condition to be part of that world:

You might say that there are the laws of each country to take into account. Indeed. But a law is something completely different from a precondition. A law applies equally to all; it does not set a precondition for belonging to the world. It is simply a provisional rule that exists in a particular region of the single world. And no one is asked to love a law, simply to obey it. ${ }^{56}$

Here, Badiou's grasp of law in the contemporary world might seem to be exceedingly 'French', permissible though such an interpretation would otherwise be from a political viewpoint privileging history or even historicity and culture over ontology, logic, and subjectivity. But it is not clear that Badiou has gone that far yet, or indeed that he will ever go that for (although he has indicated that he is aware of the task that may be laying ahead), for the simple reason that, ironically, it is politics, not the political, that constitutes the heart of Badiou's own politics.

Nevertheless we should by now begin to see Badiou's complex position regarding the relationship of politics and law. To start with, while law is on the side of the political, politics for Badiou is not. Secondly, real politics and the political (the city and its laws) are, appearances to the contrary notwithstanding, not just separate realms but also something of a 'scandal' or an obstacle to one another that both sides must deal with, yet neither side can probably remove. And so just as politics must continuously subtract itself from the political, insofar at least as the latter insists on projecting the particular fiction of parliamentary democracy at the expenses of infinite multiplicity, so conversely the political seeks at all times to overcome real politics insofar as the political needs to keep out that which, by contrast, politics is always intent on reintroducing. And, it seems to me, one duty of philosophical thought is, for Badiou, to highlight just that. It is to highlight how the political blots out the world even if, on the surface, it appears to be seeking to unite it, ${ }^{77}$ whereas politics, by contrast, aspires to unite the world even if, on the surface, it may appear to be seeking to disrupt it.

\footnotetext{
56 A. Badiou, De quoi Sarkosy est-il le nom? Circonstances, 4 (Fécamp, France: Nouvelles Editions Lignes, 2007) 63.

57 'La loi commande une multiplicité mondaine prédicative, elle donne à chaque partie du tout ce qui lui est dû.' A. Badiou, Saint Paul (Paris: Presses Universitaires de France, 1997) 82.
} 


\section{DEMOCRACY AND ART}

In the Preface to the Italian edition of the Manifeste pour la philosophie Badiou goes back to what are possibly the two key tenets of his thought. First, there is a category of Truth that, Badiou guarantees, constitutes an absolute novelty in philosophy and, importantly, is able to eschew all ways of Nietzschean criticisms levelled at metaphysical thought by being neither correspondence, nor coherence, nor usefulness, nor even unconcealment, but, rather generic singularity. Secondly, there is the acknowledgement that language is important, but there is the conviction, too, that language is not all and it is certainly not the transcendental condition of thought that old and new sophists alike claim it to be. Instead crucially, it is from the trajectory of a truth that the linguistic invention proceeds, and not the other way round. ${ }^{58}$ Or, as Badiou puts it in another essay, '[a] world, for Plato as well as for myself, can only become visible through the differences constructed within it, and singularly through the difference, in the first place between a truth and an opinion, and secondly between two truths whose type is not the same. 59

So what, for Badiou, is at stake today in the relationship between the poet and the city, between art and law? The answer is complex and to some extent uncertain, but is seems to me that such a relationship could not be properly appreciated without a few prior steps, which must be performed at once.

Firstly, we are invited to think afresh - to invent, position, and open afresh the relationship between art, philosophy, and thought or ontology as matheme, especially in consideration of the now ubiquitous didactico-romantic suture. Thus philosophy for Badiou is not art, and art is not thought, but rather something like a truth procedure immanent to thought and singular.

Secondly one must think afresh - invent, position, and open afresh - the relationship between the political (the city and its laws) on the one hand, and politics on the other hand. One will then discover that politics is not really the political, and yet it is in politics, not in the political, that new political truth-events occur.

Thirdly, philosophy cannot however produce artistic configurations or political inventions of its own. Or, philosophy can certainly think thought in its various instantiations (science, politics, art, and love), but these do not need philosophy to think themselves, and in particular to think their own respective truths. Thus the common fear that philosophy might be taking again the didactic position assigned to it by Plato would be unfounded. Instead, the task of philosophy would be to make new artistic configurations and new political

\footnotetext{
58 Badiou, $\mathrm{n} 26$ above.

59 'Tout monde, pour Platon comme pour moi, ne s'éclaire que des différences qui s'y construisent, et singulièrement de la différence, premièrement entre une vérité et une opinion, et deuxièmement entre deux vérités dont le type n'est pas le même (amour et politique, par exemple, ou art et science).' A. Badiou, 'L'emblème démocratique' in G. Agamben, et al (eds), Démocratie, dans quel'état? (Paris: La Fabrique, 2009) 19.
} 
inventions manifest in their compossibility. 'Finally, philosophy makes disparate truths compossible and, on that basis, it states the being of the time in which it operates as the time of the truths that arise within it.' ${ }^{60}$

At this point, an unexpected yet rather exhilarating question arises:

This question of the existence of truths (that 'there be truths') points to a coresponsibility of art, which produces truths, and philosophy, which under the condition that there are truths, is duty-bound to make them manifest. Basically to make truths manifest means the following: to distinguish truths from opinion. So that the question today is this and no other: is there something besides opinion? In other words (one will, or will not, forgive the provocation), is there something besides our 'democracies'? ${ }^{61}$

Thus the relationship between politics and the city and its laws on the one hand, and between politics and art or artistic configurations on the other, seems to amount, in Badiou's strictly intra-philosophical discourse, to a 'subtractive' relationship between democracy as we know it, and new forms of belonging that can and will always emerge from the central void of the contemporary situation. And this is probably one of the deepest, most interesting, and most promising challenges raised by Badiou's extraordinary interventions on art, politics, and law. For once the current links between philosophy, art, politics, and law are properly severed, at stake in the philosophical examination of the tension in late modernity between the city and its laws on the one hand, and current artistic configurations or identifiable political sequences on the other, would be precisely this, that is to say, nothing less than the future state of democracy itself. And if, as Badiou poetically puts it, 'the destiny of thought $[. .$.$] must be affirmative invention or$ nothing at all', ${ }^{62}$ then the duty of philosophy must indeed be 'to reconstitute rationally the reserve of affirmative infinity that any emancipatory project requires'.63

The truth is, for Badiou, that democracy can and must be reinvented. And that is where, today, the relationship between the poet and the city becomes crucial. The stakes, for Badiou, are high.

\footnotetext{
${ }^{60}$ Badiou, n 22 above, 14.

61 ibid, 15.

62 A. Badiou, Ethics (1998, London and New York: Verso, 2001).

63 A. Badiou, Circonstances, 1 (Clamecy: Editions Léo Scheer, 2008) 72.
} 